\title{
Literature Review on Biorefinery Processes Integrated to the Pulp Industry
}

\author{
Fernando J. B. Gomes*, Fernando A. Santos, Jorge L. Colodette, Iara F. Demuner, \\ Larisse A. R. Batalha \\ Department of Forestry Engineering, Federal University of Viçosa, Viçosa, Brazil \\ Email: ${ }^{\text {fernando.gomes@ufv.br }}$
}

Received 16 April 2014; revised 28 May 2014; accepted 19 June 2014

Copyright @ 2014 by authors and Scientific Research Publishing Inc.

This work is licensed under the Creative Commons Attribution International License (CC BY). http://creativecommons.org/licenses/by/4.0/

c) (i) Open Access

\begin{abstract}
Biorefinery is a new term to designate two main subjects, bioproducts and bioenergy, which play important roles towards a more bio-based society. This paper reviews the current biorefineries model as well as its future importance focusing on pulp mill opportunities. There are currently several different levels of integration in biorefineries which add to their sustainability, both economically and environmentally. Enzymatic pretreatment for biomass deconstruction aiming to release the polysaccharides is a key technology in the future biorefineries and it is currently the subject of intensive research.
\end{abstract}

\section{Keywords}

Lignocellulosic Biomass, Biorefinery, Ethanol

\section{Introduction}

A great challenge for the modern civilization is becoming a sustainable society based on more realistic needs and rational utilization of the natural resources. In this context, energy is one of the most important issues. Currently, the fossil fuels (oil, coal, and natural gas) are the main energy sources worldwide but their exploitation is neither sustainable nor environmental friendly.

The scientific community believes that in the near future large volumes of biomass will be processed to produce biofuels together with valuable co-products, which will be increasingly used to make other bioproducts [1]-[6]. In this scenario, certain bio-based industries such as the pulp and the sugar cane could take enormous advantage of their current knowhow in order to make intelligent use of their biomass feedstocks, by operating their facilities as biorefineries. Biorefinery is a new term that is related to two main subjects, value-added bio-

\footnotetext{
*Corresponding author.
} 
products (chemical building blocks, materials, pulps), and bioenergy (biofuels, power, and heat) from biomass, considering sustainability assessment and life cycle [7].

Many recent studies have pointed out the pulp industry as an interesting platform to deploy the biorefinery concept [8]-[10]. This industry applies partial biomass deconstruction processes for producing pulp and other products, such as paper, viscose, acetate, nitrates, lignosulphonates, vanillin, ethanol, acetic acid, etc., in addition to steam and power. The processes currently used are efficient to separate the lignin and extractives fractions from the polysaccharides; this cracking is very suitable and necessary for biorefinery applications. This paper reviews the current biorefineries model as well as its future importance focusing on cellulosic pulp mill opportunities.

\section{Biorefineries}

The emerging bio-based economy is a very promising sector with notable future potential and many business opportunities [11]; in this scenario it is includes the biorefinery concept. There are many different definitions for biorefinery, but in general the term is applied for using renewable raw materials (e.g. biomass) to produce energy together with a wide range of everyday commodities in an economic and sustainable manner [3] [7] [12] [13]. The fossil fuels (oil, coal, and natural gas) are the main energy source worldwide; however, one of the most important challenges of the modern society is in decreasing our dependency on fossil fuel reserves and boosting rural development. The biorefinery concept attempts to apply to biomass conversion, the methods that have been applied to the refining of petroleum [3]. Biorefineries would simultaneously produce biofuels as well as biobased chemicals, heat, and power. Biorefineries are seen as a very promising route to meeting our aims for sustained prosperity and preserving the environment. Unlike oil refineries, which are units of large industrial size, biorefineries should include facilities of various sizes [14].

Renewable sources of energy are required for sustainable development of our society in the near future [15]. Plant biomass is the main source of renewable materials on earth and represents a potential source of renewable energy. However, the main source of bioethanol currently used (starch from cereal seeds) is too expensive and of limited availability. By contrast, cellulose is available in high amounts at very low cost (as forest, agricultural or industrial lignocellulosic wastes and cultures) and, after overcoming some current barriers, could be a widely available and inexpensive bioethanol source in the future [7] [16] [17].

\section{Biomass Sources}

Hardwoods and softwoods have been the world's main raw materials for pulp production and they deliver suitable product quality. However, the cost of these raw materials has greatly increased in the last decade due to many factors, including the newly created demand for biorefinery applications. Therefore, the establishment of new raw materials that can compensate the lack of low cost wood has been largely sought. In this way, each one should be able to identify the ideal biomass source which should be used for biorefinery application. High productivity plants such as grasses can potentially supply biomass of low cost to meet the current demand [18]-[22]. Currently, the biomass sources are divided in two groups: woody and nonwoody.

Forest and agricultural residues have been the main target in Europe, North America and other places of temperate climate. In tropical climates like in Brazil there is great opportunity to use rapid growth and high productivity woody and nonwoody biomass to practice the Biorefinery concept. In fact, it is possible harvesting eucalypt plantations at one year of age, resembling agricultural crops, with fairly high biomass production. This has been possible due to the great improvements achieved in eucalypt biomass productivity through intensive breeding programs in the last 50 years. There exist clonal plantations in Brazil that delivers productivities of 40 ton/ha/year of bone dry wood at the age of 7 years [23]. Planted forests are very productive and homogeneous, delivering outstanding wood quality. Another relevant point is that these breeding programs have been focused on pulp and paper production and the wood quality has been tailor-made for that. When the focus is Biorefinery, there is much more to be done in regard to the understanding of the wood chemical characteristics required for this new purpose.

Regarding woody raw materials some countries and species have been highlighted, e.g. in Brazil has a forest vocation spurred by its large territorial area and tropical climate. The forested area covers more than half of the Brazilian territory (forest per capita: 2.56 ha/person), but only 7 million ha $(0.7 \%)$ is made of planted forests [24]. The Brazilian planted forests (6.7 million ha) are dominated by eucalypts (over 5.1 million ha) and Pinus 
spp (over 1.6 million ha). Some of the Brazilian planted forests are highly productive, particularly those of Eucalyptus spp (Table 1). In some areas of the Brazilian southeast and northeast Eucalyptus spp productivity can reach $80 \mathrm{~m}^{3} /$ ha/year [25]. The very high productivity of Brazilian eucalypt forests stems from the good adaptation of the species to the climate but also from the breakthrough scientific and technological advances made by Brazilian scientists and forest companies throughout the years. For example, the average productivity of the Brazilian eucalypt forests increased from $24 \mathrm{~m}^{3} / \mathrm{ha} / \mathrm{yr}$ in 1980 to $41 \mathrm{~m}^{3} / \mathrm{ha} / \mathrm{yr}$ in 2012, representing an $83 \%$ increase in productivity of planted forests in Brazil. It is expected that this productivity will reach $70 \mathrm{~m}^{3} / \mathrm{ha}^{\mathrm{ye}} \mathrm{year}$ in the near future [23].

Regarding nonwoody raw materials, there are many possibilities. Sugar cane is one of the most important biomass sources in the world, since it can be used as a food resource (e.g. sugar) or raw material to produce renewable fuels (e.g. ethanol). The sugar cane (Saccharum spp) is an interesting raw material for biorefinery since it can provide the following materials: 1) sugars (sucrose, glucose, and xylose); 2) natural polymers (cellulose, hemicellulose, and lignin present in the bagasse and straw); 3) stillage rich in organic raw material; and 4) other compounds, such as alcohols and carbon dioxide $\left(\mathrm{CO}_{2}\right)$.

Currently, the biorefinery concept applied to sugar cane has focused on the production of first generation ethanol (from extracted sugar cane juice), and second generation ethanol (from cellulose). There are three new plants planned for the year 2014 for producing second generation ethanol in Brazil using a biorefinery model [24]. The second generation ethanol will largely enhance the total ethanol that can actually be produced from sugar cane. For example, the average sugar cane productivity in Brazil is 85 tons per hectare, and for each ton of sugar cane processed about $140 \mathrm{~kg}$ dry-matter of bagasse and $140 \mathrm{~kg}$ dry-matter of straw are generated, i.e., 12 tons of straw and 12 tons of bagasse per hectare [5]. The estimated current total global production of first generation ethanol from sugar cane is 20 billion liters a year [25]. When using the sugar cane bagasse and straw in a biorefinery model, the theoretical ethanol yield (considering that all glucose will be converted to ethanol) would be improved by approximately $98.4 \%$, i.e., the current production could be increased to 49.7 billion liters a year [5].

The use of the sugar cane bagasse residue after sugar extraction to produce second-generation biofuel (e.g. ethanol) has been extensively studied due to its wide availability and low cost [5] [26]. However, the process of using sugarcane bagasse residues to produce ethanol is not cost-effective due to high energy consumption required for a harsh pretreatment process, a complicated detoxification process and the use of expensive enzymes for polysaccharide hydrolysis [27].

Another potential nonwoody raw material is the elephant grass (Pennisetum spp) which is highly effective in the $\mathrm{CO}_{2}$ fixation during the photosynthesis process for biomass production. Reference [2] [18]-[20], obtained different results of biomass production from elephant grass (cultivar "Paraíso") due to the various treatments in their research works. The total production of biomass with $85 \%$ of dry matter is 27 ton/ha and may be stored for an indefinite period of time. In accordance with reference [22], the advantages of elephant grass as biomass source in relation to other sources are: greater productivity (45 t dry-matter/ha/year), shorter productive cycle (two cuts per year), better cash flow, possibility of total mechanization, and greater assimilation of carbon. Some characteristics of elephant grass compared with sugar cane bagasse are reported by reference [28]. Elephant grass has special potential for biorefinery applications because of its high fiber production of adequate chemical composition, similar to sugar cane bagasse in many senses [28] [29]. Some studies on elephant grass have shown a

Table 1. Annual productivity of main Brazilian planted forests [24].

\begin{tabular}{cc}
\hline Species & Productivity, $\mathbf{~ m}^{\mathbf{3}} \mathbf{h a} \mathbf{\text { year }}$ \\
\hline Acacia (Acacia spp) & $15-25$ \\
Araucaria (Araucaria angustifolia) & $10-25$ \\
Aspen (Populus deltoides) & $20-30$ \\
Eucalypt (Eucalyptus spp) & $30-40$ \\
Pine (Pinus spp) & $25-30$ \\
Teak (Tectona grandis) & $15-20$ \\
\hline
\end{tabular}


content of $40 \%, 30 \%$ and $17.7 \%$ for cellulose, hemicelluloses and lignin, respectively [30]. These values are adequate for biorefinery applications, in special the low lignin content that indicate an easier fractionation of this material in deconstruction processes.

Another characteristic of elephant grass is that in the stalks, the fiber content is frequently higher than in leaves (53\% and $45 \%$ - 46\%, respectively), as well as lignin ( $11 \%$ and $9 \%$, respectively) and cellulose ( $40 \%-41 \%$ and $29 \%$ - 30\%, respectively) [29]. Another important parameter to take into account is the amount of energy produced per hectare per year. In average, elephant grass can produce 190,000 Mcal/ha/year whereas eucalypt produces about 100,000 and sugar cane bagasse only 30,000.

\section{The Pulp Mills as Biorefineries Platform}

The major components of all lignocellulosic materials are cellulose, hemicelluloses, and lignin, which have the structural formulae $\mathrm{CH}_{1.67} \mathrm{O}_{0.83}, \mathrm{CH}_{1.64} \mathrm{O}_{0.78}$, and $\mathrm{C}_{10} \mathrm{H}_{11} \mathrm{O}_{3.5}$, respectively [31]. There are also other compounds in minor proportion such as proteins, lipids, pectin, soluble sugars and minerals [32] [33]. In its native state, lingocellulosic material is recalcitrant to efficient hydrolysis of its cellulose fraction into glucose monomer due to the physicochemical and structural composition of the material [34]. The most important carbohydrates present in the biomass plant are shown in the Figure 1. Partial deconstruction of biomass to make paper pulp is a quite well known and established technology and aimed to separate cellulose and hemicelluloses fractions from the lignin, extractives and minerals. However, deconstruction aimed at production of biofuels and biomaterials other than paper pulp is still a great challenge [35] [36]. Although lignocellulosic biomass is a very promising biofuel and bioproducts source, it cannot be currently commercially exploited mainly due to limitations for chemical or enzymatic hydrolysis caused by the presence of lignin. If this drawback is solved, low cost wood materials can be the source of choice to obtain renewable energy in the near future.

Thus, the optimization of pretreatment methods for deconstructing biomass into their cellulose, hemicelluloses and lignin fractions is of great importance for the pulp and paper, biofuel and bioproducts industry [37]-[39]. Such optimization requires a particular emphasis on the development of analytical methods for the characterization of the structural (cellulose, hemicelluloses, lignin) and non-structural (lipids, minerals, etc.) biomass constituents and the study of their fate during the pretreatment and deconstruction process. This is particularly true when dealing with unknown faster growing feedstocks such as elephant grass.

Partial deconstruction of lignocellulosic biomass to make paper pulp is currently done with the secular kraft process, which delivers a high quality product. This process is efficient to separate the lignin and extractives fractions from the polysaccharides, but the lignin fraction becomes contaminated with sulfur, which hinders its utilization in many applications and creates air pollution problems. If lignin were free from sulfur, they could potentially be more easily recovered for producing energy and as a phenol source for many applications such as carbon fiber, activated carbon and other aromatic added-value chemicals [40] [41]. Among the non-sulfur partial deconstructing biomass processes currently known, the soda-anthraquinone (AQ) and organosolv processes are included [42]. Partial deconstruction by these methods have been largely studied in the past and proven non-
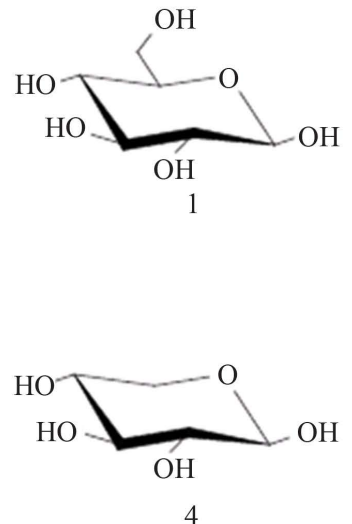
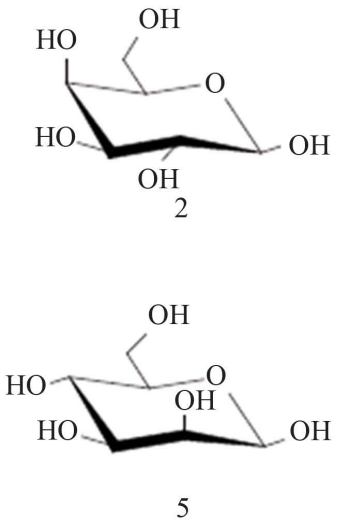
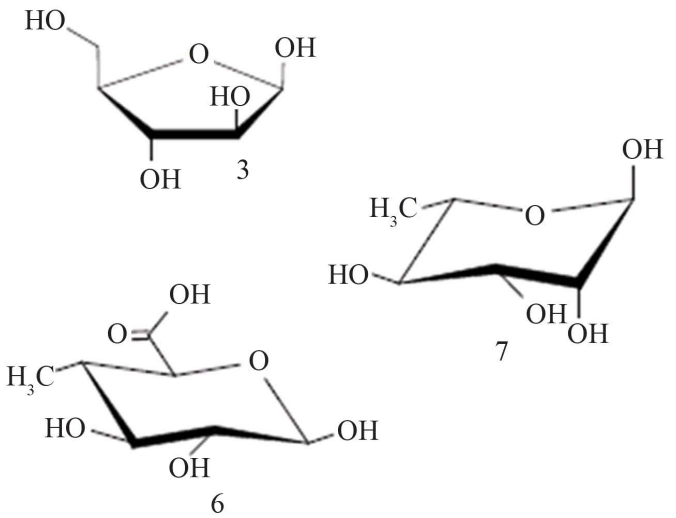

Figure 1. Important plant carbohydrates: (1) D-glucose, (2) D-galactose, (3) L-arabinose, (4) D-xilose (5) D-mannose, (6) 4-O-metil-D-glicuronic, (7) L-Rhamnose. 
competitive with the kraft process mainly due to the low paper pulp product quality.

Nevertheless, in the context of operating a pulp mill as a Biorefinery, where wood is not the unique feedstock and paper pulp is not the only product within the value added product chain, such processes may become more interesting than the kraft (Figure 2). For example, the quality of the paper pulps derived from these processes may be improved by incorporating to them some fractions of the deconstruction process such as hemicelluloses [43]. Other paper products less demanding in regard to strength can be made from these pulps without penalty [43]. A significant part of the pulp produced can be actually directed towards biofuel and biomaterials production, and in this case strength is not an issue. Furthermore, in all these alternative pulping methods the black liquor derived from biomass deconstruction is much more amenable for recovery than that of the kraft process, both for energy and lignin separation and conversion into biomaterials.

\section{The Biochemical Platform in Lignocellulose Biofuels}

Another option that a biorefinery should contemplate is the complete biomass deconstruction without going through paper pulp production. This can be done by two different routes, the biochemical and the thermochemical conversions. In both cases biochemical intermediates and residues are produced with the first being used for fuels, chemicals and materials production, and the residues used for combined heat and power generation. Although both routes are promising, the biochemical platform integrates better with a paper pulp manufacturing facility.

The biochemical platform converts the carbohydrate fraction into fermentable sugars, leaving lignin and other fractions as a residue. There are several approaches to this, including: 1) separate hydrolysis and fermentation; 2) simultaneous saccharification and fermentation; 3) simultaneous saccharification and co-fermentation and 4) consolidated bioprocessing [5] [44]. In the first approach the C5 sugars are firstly hydrolyzed under acidic conditions and the solids remaining are treated with cellulases to produce C6 fermentable sugars, leaving lignin and other materials as residues. In the second case the C5 sugars are firstly hydrolyzed under acidic conditions and the solids remaining are scarified/fermented simultaneously to produce bioethanol, leaving lignin and other materials as residues. In both cases, the C5 and C6 sugars are fermented separately. The third scenery suggests a similar route as the second, except that C5 and C6 sugars are fermented together. The fourth route is still a theory, but may become reality in the future, and suggests the acid hydrolysis of C5 sugars followed by cellulases production, hydrolysis of C6 and co-fermentation of C5 and C6 in a single reactor, leaving lignin and other materials as residues.

In the biochemical platform, acid hydrolysis is the conventional method for the liberation of simple sugars for fermentation; however, it is not the ideal method, since compounds such as furfural and hydroxymethylfurfural are formed as side products, which are toxic for the yeasts, and thus lower the fermentation yield [5]. To avoid the formation of toxic compounds, it would be desirable to accomplish the saccharification step enzymatically using a combination of hydrolytic enzymes. However, the complex structure of the fiber wall, being composed of a matrix of entangled polymers of cellulose, hemicellulose, lignin and protein, depending on the plant material, complicates the enzymatic hydrolysis. In practice, a pretreatment stage is required to loosen the cell wall struc-

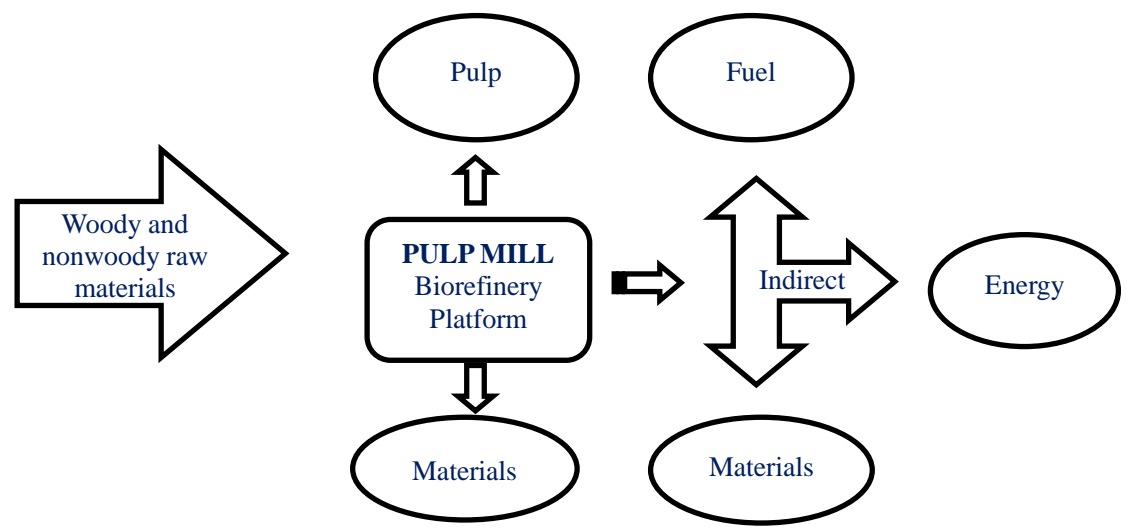

Figure 2. Pulp mill working as a biorefinery platform for producing chemicals, energy, fuels, and materials. 
ture and/or remove lignin and other non-carbohydrate components in order to expose cellulose and the hemicelluloses [37] [38] [45]-[47].

\subsection{Pre-Treatments Based on the Bost Usual Pulping Technologies}

Pretreatment refers to the mechanical, physical, chemical, and/or biological treatments to reduce the particle size of the material and disrupt its cell structure to make it more accessible to chemical or enzymatic hydrolysis treatments [5] [48]. More specifically, the aims of pretreatment are typically the hydrolysis of hemicelluloses and reduction of crystallinity and degree of polymerization of cellulose, to facilitate the subsequent enzymatic hydrolysis of cellulose [48].

The most used pretreatments include: 1) Ball mill, which is based on a type of grinder used to grind biomass into extremely fine powder, being effective for a decrease in the cellulose crystallinity and improve the enzyme digestibility [49]; 2) Diluted acid, which is based on the use of diluted acids such as sulfuric and phosphoric acid at high temperature $\left(140^{\circ} \mathrm{C}-200^{\circ} \mathrm{C}\right)$ for up to 1 hour, aiming the hydrolyzes of the hemicelluloses fraction of the biomass to soluble sugars while the lignin condenses and precipitates [45] [50] [51]; 3) Ammonia Recycle Percolation- $A R P$, which is a pretreatment method based on aqueous ammonia, aiming the enzymatic digestibility and also achieves high degree of delignification [52] [53]; 4) Alkaline pretreatments: sodium hydroxide and calcium hydroxide, they causes the lignocellulose to swell, thereby increasing the surface area while reducing the degree of polymerization and crystallinity of the material, these processes can be performed at ambient temperatures and pressures, although longer reaction times may be needed in this case [37] [45] [51] [54]; 5) Ozonolysis, which is based on biomass ozone application, this pretreatment has shown its efficacy essentially degrading the lignin polymer but also slightly solubilizing hemicellulose content of lignocellulosic biomass [55] [56]; 6) Organosolv, which is based on the organic solvents or their aqueous solution for extracting lignin from lignocellulosic raw materials at high temperatures; the main difference between organosolv pretreatment and organosolv pulping process is the delignification degree, which is not demanded to be as high as that for pulping [57]; 7) Biological, which is based on the use of microorganisms and their enzymatic machineries to break down lignin and alter lignocellulose structures [58]; 8) Steam explosion, which is based on the use of water at high temperature in a pressurized reactor prior a rapid decompression, providing an explosion, which effectively breaks bonds between the lignin and hemicellulose fractions, allowing the material to expand and expose the cellulose; 9) Ammonia fiber expansion-AFEX, is similar to that of steam explosion, except the biomass soaks in liquid ammonia instead of water in a pressurized reactor prior to rapid decompression; in this process the recycle of the ammonia would be required to make this option economically feasible [51]. In Table 2 the effects of various pretreatments are presented.

\subsection{Kraft and Soda-AQ Pulping of Fast Growth Feedstocks}

Biomass deconstructions through the alkaline process are quite well known and are the most used processes for converting the wood into pulp. Currently, the main pulping process used worldwide is the kraft one, which uses sodium hydroxide and sodium sulphide as reagents; its hegemony in the world comes from the fact that it produces pulp of high strength, uses any type of biomass, possesses a highly developed chemical recovery technology and is the most selective of all chemical processes known [25] [59] [60].

Concerning the alkaline processes, these are well established technologies for pulping, however targeting a new pulp industry working as a biorefinery, some characteristics of the processes should be considered, such as sulfur free technologies, since compounds containing this element are responsible for decreasing the black liquor heating value, for example [59]. Additionally, benefits of using sulfur free processes may be also interesting for decreasing environmental pressures, since the elimination of sulfur from the processes will greatly decrease aerial emissions of the reduced sulfur compounds usually produced by the kraft process [42]. Soda process also appears as an interesting alternative, since the mill structure is compatible with the kraft process. The interest in sulfur free pulping has centered on soda pulping with anthraquinone (AQ) additions, since its presence accelerates delignification during soda pulping and produces pulps with strength properties which approach kraft levels [42] [60].

Regarding the pulping process characteristics, selectivity is a significant parameter when the pulp strength properties are relevant. In this case the kraft process is the ideal choice, since it is well known to deliver the best fibers. Although selectivity is still important in the deconstruction for biofuel and bioproducts (yield) it play a 
Table 2. Effect of different pretreatments in lignocellulosic biomass [5].

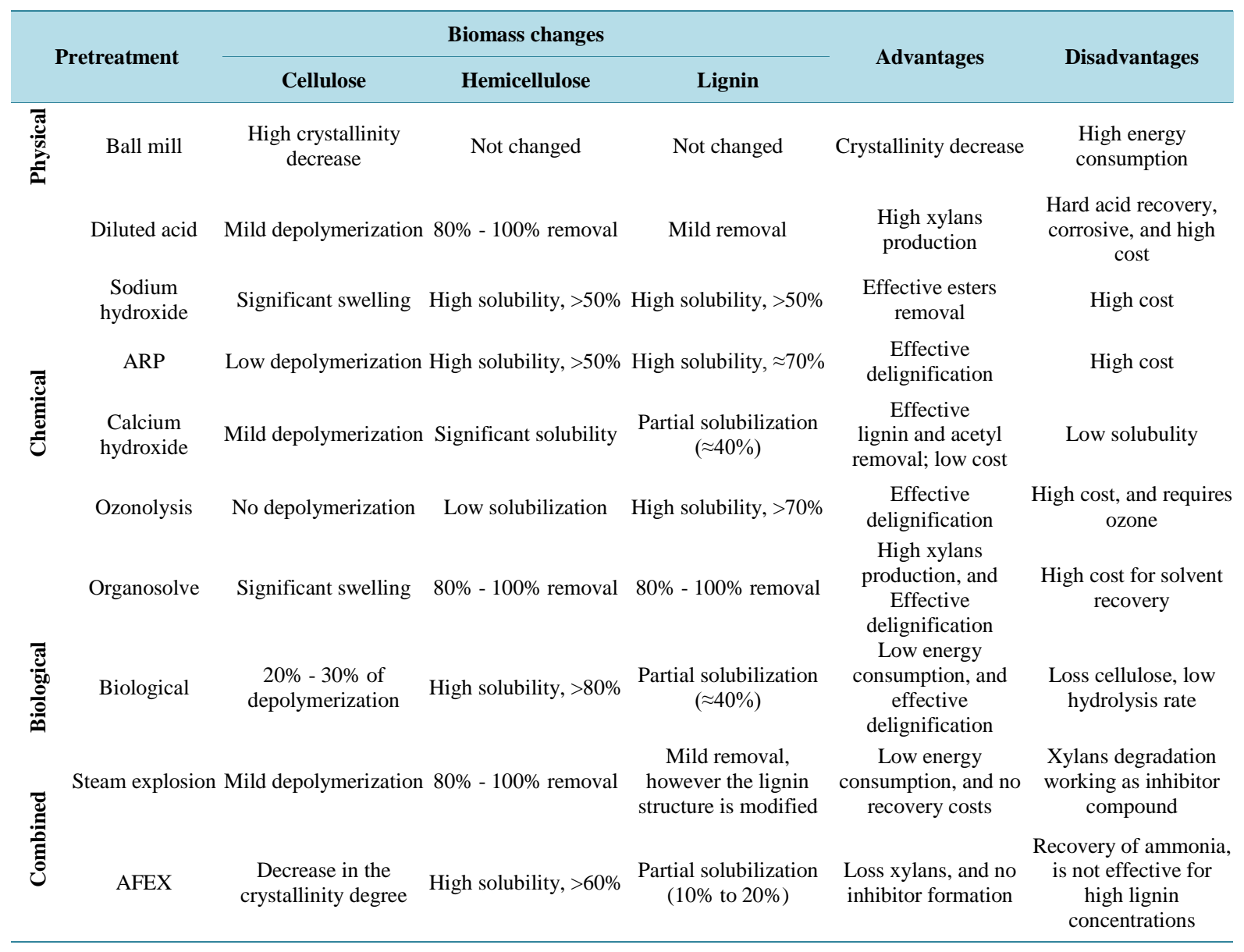

less important role since the fiber integrity is no longer important. In this way, the resulting black liquor free of sulfur offers more opportunities for lignin use than the kraft one.

Most modifications of the kraft process have been aimed at improving yield and the properties of the pulp produced. AQ has been used as an additive to the soda and kraft pulping processes due to improved delignification rate and protection of cellulose and hemicelluloses chains against peeling reactions. The benefits of using AQ in eucalypt kraft pulping have been proven by many authors [42] [60]-[62].

Emissions of total reduced sulfur compounds (TRS) in a kraft pulp mill have been an environmental concern. They are corrosive and responsible for the bad odor of the kraft process. TRS compounds are generated during pulping and are liberated mainly from digester together with steam. TRS formation during pulping depends on sulphidity level, pulping time and pulping temperature. Some decrease in TRS compounds emissions have been obtained by reducing pulping sulphidity [42] [63]-[65]. Use of low or zero sulfidity and addition of AQ can be an alternative to reduce pollutant emission without decreasing delignification efficiency [42] [66]. One alternative that can be used is the Soda-AQ process.

The use of Soda process catalyzed by AQ would have additional benefits by reducing mill odors, simplifying the recovery process, and allowing gasification technology to be utilized for recovery. On the other hand, the Soda-AQ process has well-known drawbacks, including the high AQ cost and the production of pulp with lower tear strength [67]. These drawbacks account for the limited implementation of Soda-AQ pulping to a few hardwood pulp mills. On the other hand, if the Soda-AQ pulp is used to produce biofuel rather than paper pulp, the strength problem is not a problem. The financial considerations for AQ pulping technologies have been improved over the past decade. First, the cost of AQ has decreased substantially over the past few years, as the AQ pulping patents have lapsed, new inexpensive off-shore AQ production facilities have been established, and several new AQ derivatives have been reported in the literature that exhibit improved activity [68]. 


\subsection{Organosolv Pre-Treatment}

With that focus, organosolv pulping processes have very few advantages compared to the traditional kraft process. However, organosolv processes may turn out to be potential as pre-treatment technologies for bioethanol production, aiming at delignification and opening of the cell wall matrix [48].

According to reference [69], a successful organosolv process for the replacement of the kraft process has the following characteristics (even if some of them are specific to paper grade pulp, most are relevant also in case of bioethanol as the target product): 1) totally sulfur free; 2) solubilization of most of the lignin with little loss of cellulose and hemicelluloses; 3) moderate temperature, pressure and pulping times; 4) efficient and simple chemical recovery system; 5) no environmental problems; 6 ) the optimal size of the process smaller than that of the kraft process; 7) applicable to broad selection of raw materials; 8) recovery of valuable by-products; 9) high pulp quality; 10) good bleachability without chlorine chemicals; 11) high pulp yield; 12) low energy consumption of the process; and 13) closed chemical cycle of the process.

The search for pulping processes that could fulfill the requirements listed above has led to the development of several organosolv methods capable of producing pulp with properties near those of kraft pulp. The Organocell (methanol), ASAM (methanol), Acetosolv (acetic acid) and Milox (peroxyformic acid) processes were tested either in pilot or full scale, but none of them led to continued production [70]-[75].

Nonwoody raw materials differ from wood in their chemical composition, especially concerning their high silica content which is problematic in kraft or soda cooking; during the delignification process, the silica present in the raw material dissolves into the cooking liquor, which has led to difficulties in the recovery chemicals system. Organosolv processes are therefore especially interesting for nonwoody raw materials, and at least the formic acid process has been commercialized [76]. The Lignofiber (LGF) process is a novel versatile organosolv method that fulfills most of the requirements listed previously, being applicable for annual plants as well as wood raw materials [77].

\subsection{Enzymes as Potential Cell-Wall Deconstructing Biocatalysts}

Several enzyme types are involved in natural biomass degradation [78] [79]. Many lignocellulose degrading enzymes work in a hydrolytic reactions system (mainly acting on hemicelluloses), while others works as oxidoreductive ones (mainly acting on lignin) [79]. Cell wall decay is a sequential process where lignin removal is generally the first and rate limiting step. When the cell wall protection due to the recalcitrant lignin is removed, the polysaccharides are susceptible towards attack by hydrolytic enzymes; however, an initial degradation of lignin-polysaccharide linkages can be produced in some cases [38] [80].

\subsubsection{Lignin-Degrading Enzymes}

Lignin is an aromatic heteropolymer consisting of three monolignols, methoxylated to various degrees: coniferyl alcohol, sinapyl alcohol and p-coumaryl alcohol. These monolignols are incorporated into lignin in the form of guaiacyl (G), syringyl (S) and $p$-hydroxyphenyl $(\mathrm{H})$, respectively. Lignin are natural glues that bind tightly to polysaccharides, complicating our understanding of its native structure; the lignin-polysaccharide presents covalent and other linkage types, whose nature varies in different plants [81] [82] resulting in different susceptibilities towards enzymatic deconstruction. Whereas direct linkages between polysaccharide and lignin exist in wood, this association in most nonwoody angiosperms involves $p$-hydroxycinnamic acids forming lignin-polysaccharide bonds [83]. In first studies on enzymatic degradation of lignin during the 1970s the involvement of a variety of enzymes was considered [84]. This was because of the structural complexity of the lignin polymer (formed by different units and inter-unit linkages) that, according to the classic concept of enzyme-substrate specificity, suggested different enzyme types acting on the different substrate substructures. However, the main lignin degrading organisms (the so-called white-rot fungi because of the whitish color of the cellulose enriched substrate after lignin removal) have solved the problem of lignin heterogeneity just in the opposite way. The current evidence indicates that they have developed a unique degradation mechanism based on high redox-potential oxidoreductases, which often act in combination with redox mediators increasing their oxidative power [85]. These enzymes include laccases (fungal phenoloxidases) and ligninolytic peroxidases, the so-called lignin peroxidase (LiP), manganese peroxidase (MnP) and versatile peroxidase (VP), acting in synergy with $\mathrm{H}_{2} \mathrm{O}_{2}$-producing oxidases, among other enzymes [86]-[88].

Lignin degradation by the above oxidoreductases has been defined as an "enzymatic combustion" [89] be- 
cause of the unspecific enzymatic attack, which is directed towards the benzenic ring of the lignin substructures. This results in a variety of subsequent side-reactions of the aromatic cation radical formed resulting in ether and side-chain breakdown (leading to depolymerization), demethoxylation, and even aromatic-ring opening. Because of the bulky nature of lignin, the lignin-degrading peroxidases have developed a noteworthy mechanism enabling oxidation of the polymer at the enzyme surface by an exposed protein radical, and subsequent longrange electron transfer to the peroxide-activated heme cofactor (that is located in a central pocket) [85] [90]. An alternative is the use of redox mediators, simple compounds that form diffusible stable radicals once oxidized by the enzyme, acting at distance and even when the access to the lignin polymer is limited by steric hindrances (such as the compact structure of the plant cell-wall in undecayed materials). These mediators have been largely investigated for their use in combination with laccases in different industrial applications including paper pulp delignification in totally chlorine free industrial-type bleaching sequences [91].

\subsubsection{Hemicellulose-Degrading Enzymes}

Hemicelluloses vary in their constitutive monosaccharide units, as well as in their branching and acetylation degrees. Therefore, a variety of glycosidases and esterases are involved in hemicellulose degradation [92]. The former are often 1,4- $\beta$-glycosidases, since 1,4-linkages predominate among hemicellulose units, whereas the latter mainly include acetyl-esterases releasing acetic acid from acetylated units, but also feruloylesterases breaking down the lignin-polysaccharide bridges mentioned above. Hemicellulose deacetylation can affect the substrate specificity of glycosidases involved in subsequent depolymerization [82], and is also of technological interest in biomass pre-treatment since the acetic acid released can contribute to lignin depolymerization by solvolysis reactions (as occurs in the organosolv processes).

Pectinases are important for cell-wall deconstruction in non-fully lignified tissues, where pectin in primary wall acts as the intercellular gluing agent. Since hemicelluloses occupy an intermediate position in the lignocellulosic matrix, being covalently-linked to lignin (directly or via cinnamic bound) and establishing hydrogen bond interactions with cellulose, its degradation often results in cell-wall deconstruction and separation of its two main constituents, cellulose and lignin. In a similar way, xylanases are used for years in the industrial bleaching of paper pulp [88], since xylan hydrolysis facilitates the removal of the residual lignin remaining in the paper pulp.

\subsubsection{Cellulose-Degrading Enzymes}

Although cellulose is a simple polymer formed by cellobiose units, several enzymes (different 1,4 - $\beta$-glucosidases) are involved in its hydrolytic breakdown [93]. These include the so-called endoglucanases breaking down internal glycosidic bonds in the cellulose polymer, a process that results in a decrease of molecular mass (polymerization degree). On the contrary, 1,4-cellobiohydrolases (exocellulases) release the cellobiose units from cellulose chain-ends, which are hydrolyzed by cellobiases ( $\beta$-glucosidases) yielding free glucose. The action of the latter enzymes is facilitated by the depolymerizing action of the above endoglucanases that increase the number of chain-ends susceptible of attack by exocellulases. The action of cellulases is facilitated by the existence of conserved cellulose-binding domains in their molecular structure. The bacterial cellulosomes are suggestive examples of complex multienzymatic systems including different carbohydrate hydrolases and carbohydratebinding modules on a common scaffold for their concerted action on a lignocellulosic substrate [94]. Crystallinity is a main bottleneck for cellulose hydrolysis by cellulase complexes and some proteins lowering the crystallinity degree have been also described in cellulolytic organisms, such as fungal swollenins [95]. Moreover, an extended attack on crystalline cellulose, without the previous removal of lignin, is produced by brown-rot fungi.

In the same way that the unique ligninolytic oxidoreductases produced by white-rot fungi are of enzymes of interest as industrial biocatalysts, the so-called brown-rot fungi have developed a noteworthy mechanism for the selective removal of wood carbohydrates leaving a lignin-enriched residue [96] that could be applied in lignocellulose biorefineries. Recent studies, including the complete sequencing of the first genome of a brown-rot fungus at the DOE Joint Genome Institute (www.jgi.doe.gov) have shown that their ability to use lignin, without a previous removal of the lignin barrier, is based on the enzymatic generation of hydroxyl radical in the socalled Fenton reaction (consisting of peroxide reduction by ferrous iron). The hydroxyl free radical is one of the strongest oxidizers involved in biological reactions, depolymerizing cellulose even in its crystalline state. These findings suggest the feasibility of a biomimetic approach based on Fenton chemistry to improve polysaccharide hydrolysis for the subsequent production of bioethanol and other products from the lignocellulosic biomass. 


\subsubsection{Other Enzymes}

In addition to the above enzymes, other enzymes with a potential interest in cell-wall deconstruction participate in the natural decay of lignocellulosic biomass. These include, among others, lipases hydrolyzing triglycerides representing a significant percentage of lipophilic extractives, and esterase and glycosidase hydrolyzing sterol esters and glycosides also present in this fraction [97]-[100]. Proteins also represent a minor fraction in lignocellulosic materials (together with the water-soluble material containing free sugars), and proteases (peptidases) hydrolyzing the amide type peptidic bonds can be of interest in the isolation of cell wall constituents [100].

\section{Conclusion}

Biofuels e.g. bioethanol, are important in the future because they replace petroleum-based fuels, and they can be obtained from renewable sources such as sugar cane, corn, straw, grasses and wood. There are currently several different levels of system integration for biofuel production which add to their sustainability, both economically and environmentally. The pulp industry appears as a very interesting opportunity, since it already has efficient process to separate the lignin and extractives fractions from the polysaccharides; this cracking is very suitable and necessary for biorefinery applications. Efficient enzymatic conversion of lignocellulosic polysac-charides into sugars is a key technology in the future biorefineries and is currently the subject of intensive research.

\section{Acknowledgments}

Funding provided by the European Community's Seventh Framework Programme FP7/2007-2013 under grant agreement no KBBE-2009-3-244362 LignoDeco, from the Minas Gerais State Research Foundation (FAPEMIG) and from the Brazilian National Council for Science and Technology Development (CNPq) is greatly appreciated.

\section{References}

[1] Demirbas, A. (2008) Economic and Environmental Impacts of the Liquid Biofuels. Energy Education Science and Technology, 22, 37-58.

[2] Balat, M. (2009) New Biofuel Production Technologies. Energy Education Science and Technology Part A, 22, 147161.

[3] Dermibas, M.F. (2009) Biorefineries for Biofuel Upgrading: A Critical Review. Applied Energy, 86, S151-S161. http://dx.doi.org/10.1016/j.apenergy.2009.04.043

[4] Börjesson, P. (2009) Good or Bad Bioethanol from a Greenhouse Gas Perspective-What Determines This? Applied Energy, 86, 589-594. http://dx.doi.org/10.1016/j.apenergy.2008.11.025

[5] Santos, F.A., de Queiróz, J.H., Colodette, J.L., Fernandes, S.A., Guimarães, V.M. and Rezende, S.T. (2012) Potencial da palha de cana-de-açúcar para produção de etanol. Química Nova, 35, 1004-1010.

[6] Gupta, K.V. and Tuohy, M.G. (2013) Biofuel Technologies: Recent Developments. Springer, Berlin, 534 p.

[7] Aresta, M., Dibenedetto, A. and Dumeignil, F. (2013) Biorefinery: From Biomass to Chemicals and Fuels. Green Processing and Synthesis, 2, 87-88.

[8] Axegard, P. (2006) Status of the Bio-Refinery Development in Scandinavia. Forum on Energy: Immediate Solutions, Emerging Technologies, Appleton, 15-17 May 2006.

[9] Larson, E. (2007) Pulp Mill Integrated Gasification-Based Liquid Biofuels Production. International Renewable Energy Conference, Atlanta, 10-11 May 2007.

[10] Foster, B.L., Dale, B.E. and Doran-Peterson, J.B. (2001) Enzymatic Hydrolysis of Ammonia-Treated Sugar Beet Pulp. Applied Biochemistry and Biotechnology, 91-93, 269-282. http://dx.doi.org/10.1385/ABAB:91-93:1-9:269

[11] Luoma, P., Vanhanen, J. and Tommila, P. (2011) Distributed Bio-Based Economy—Driving Sustainable Growth, Sitra. http://www.sitra.fi/julkaisu/2011/distributed-bio-based-economy

[12] Zhang, Y.H.P. (2008) Reviving the Carbohydrate Economy via Multi-Product Lignocellulose Biorefineries. Journal of Industrial Microbiology Biotechnology, 35, 367-375. http://dx.doi.org/10.1007/s10295-007-0293-6

[13] Himmel, M.E. (2008) Biomass Recalcitrance. Deconstructing the Plant Cell Wall or Bioenergy. Blackwell, Oxford.

[14] Rodrigues, J.A.R. (2011) From the Mill to a Biorefinery: The Sugar Factory as an Industrial Enterprise for the Generation of Biochemicals and Biofuels. Química Nova, 34, 1242-1254. http://dx.doi.org/10.1590/S0100-40422011000700024 
[15] Dewulf, J. and Van Langenhoven, H. (2006) Renewables-Based Technology. Sustainability Assessment. John Wiley \& sons, Chichester. http://dx.doi.org/10.1002/0470022442

[16] Gray, K.A., Zhao, L.S. and Emptage, M. (2006) Bioethanol. Current Opinion in Chemical Biology, 10, 141-146. http://dx.doi.org/10.1016/j.cbpa.2006.02.035

[17] US DOE (2006) Breaking the Biological Barriers to Cellulosic Ethanol. A Joint Research Agenda (doe/sc-0095).

[18] Vilela, H., Rodriguez, N. and Dias Teixeira, E. (1997) Produções de forragem de um híbrido hexaplóide (Pennisetumglaucum X Pennisetumpurpureum) e seu valor nutritivo. In: Anais da XXXIV Reunião da SBZ, Juiz de Fora, Julho de 1997.

[19] Vilela, H., Barbosa, F.A. and Rodriguez, N. (2001) Qualidade das silagens de capim elefante Paraíso submetidas a três tempos de emurchecimento. Anais: XXXVIII Reunião Anual da Sociedade Brasileira de Zootecnia, Piracicaba, Julho de 2001, 323-324.

[20] Vilela, H., Barbosa, F.A., Rodriguez, N., Benedetti, E. and Nogueira, A.C. (2002) Produção e composição química do capim elefante Paraíso submetida a três alturas de corte. Anais da XXXIX Reunião Anual da Sociedade Brasileira de Zootecnia, Recife, Julho de 2002.

[21] Paulino, V.T., De Lucenas, T.L. and Possenti, R.A. (2007) Capim elefante cv. Paraíso (Pennisetumhybridum): Produção de matéria seca, composição química e biológica em diferentes alturas de corte. http://www.iz.sp.gov.br/artigos.php?ano=2007

[22] Mazzarella, V.N.G. (2007) Jornada Madeira Energética-Capim Elefante com Fonte de Energia no Brasil: Realidade Atual e Expectativas. IPT-BNDS, Rio de Janeiro, Maio de 2007.

[23] Associação dos Fabricantes de Celulose e Papel—BRACELPA (2013) http://www.bracelpa.com.br

[24] (2012) SBS: Sociedade Brasileira de Silvicultura. www.sbs.org.br.

[25] Gomes, F.J.B., Colodette, J.L., Burnet, A., Batalha, L.A.R. and Barbosa, B.M. (2013) Potential of Elephant Grass for Pulp Production. BioResources, 8, 4359-4379.

[26] Patel, M.A., Ou, M.S., Ingram, L.O. and Shanmugam, K.T. (2005) Simultaneous Saccharification and Co-Fermentation of Crystalline Cellulose and Sugar Cane Bagasse Hemicellulose Hydrolysate to Lactate by a Thermotolerant Acidophilic Bacillus sp. Biotechnology Progress, 21, 1453-1460. http://dx.doi.org/10.1021/bp0400339

[27] Wang, L., Tong, Z., Ingram, L.O., Cheng, Q. and Matthews, S. (2013) Green Composites of Poly (Lactic Acid) and Sugarcane Bagasse Residues from Bio-Refinery Processes. Journal Polymer and the Environment, 21, 780-788. http://dx.doi.org/10.1007/s10924-013-0601-3

[28] Seye, O., Cortez, L.A.B. and Gómez, E.O. (2000) Queima direta de gramínea Projeto Integrado de Biomassa—PIB. In: ENCONTRO DE ENERGIA NO MEIO RURAL, 3, Campinas. http://www.proceedings.scielo.br/scielo.php?script=sci_arttext\&pid=MSC0000000022000000200001\&lng=en\&nrm=a $\underline{\text { bn }}$

[29] Quesada, D.M., Boddey, R.M., Massena Reis, V. and Urquiaga, S. (2004) Parâmetros Qualitativos de Genótipos de Capim Elefante (Pennisetum purpureum Schum.) estudados para a produção de energia através da Biomassa. Circular Tècnica, 8, 4 p.

[30] Madakadze, I.C., Masamvu, T.M., Radiotis, T., Li, J. and Smith, D.L. (2010) Evaluation of Pulp and Paper Making Characteristics of Elephant Grass (Pennisetum purpureum Schum) and Switchgrass (Panicum virgatum L.). African Journal of Environmental Science and Technology, 4, 465-470.

[31] Sixta, H., Süss, H.U., Potthast, A., Schwanninger, M. and Krotscheck, A.W. (2006) Pulp Bleaching. In: Sixta, H., Ed., Handbook of Pulp, Wiley-VCH, Weinheim, 609-932. http://dx.doi.org/10.1002/9783527619887.ch7a

[32] Pauly, M. and Keegstra, K. (2008) Cell-Wall Carbohydrates and Their Modification as a Resource for Biofuels. Plant Journal, 54, 559-568. http://dx.doi.org/10.1111/j.1365-313X.2008.03463.X

[33] Gomes, F.J.B. (2010) Bleaching Improvement of Kraft Pulp in Wood Mixture of Pinus spp. and Eucalyptus spp. by the Sequence OQD*(PO) and OQD*(PO) DP. Master Dissertation, Federal University of Viçosa, Viçosa.

[34] Himmel, M.E., Ding, S.H., Johnson, D.K., Adney, W.S., Nimlos, M.R., Brady, J.W. and Foust, T.D. (2007) Biomass Recalcitrance: Engineering Plants and Enzymes for Biofuels Production. Science, 315, 804-807. http://dx.doi.org/10.1126/science.1137016

[35] Ragauskas, A.J., Nagy, M., Kim, D.H., Eckert, C.A., Hallet, J.P. and Liotta, C.L. (2006) From Wood to Fuels: Integrating Biofuels and Pulp Production. Industrial Biotechnology, 2, 55-65. http://dx.doi.org/10.1089/ind.2006.2.55

[36] Kadam, K.L., Chin, C.Y. and Brown, L.W. (2008) Flexible Biorefinery for Producing Fermentation Sugars, Lignin and Pulp from Corn Stover. Journal of Industrial Microbiology \& Biotechnology, 35, 331-341. http://dx.doi.org/10.1007/s10295-008-0322-0

[37] Hendriks, A.T. and Zeeman, G. (2009) Pretreatments to Enhance the Digestibility of Lignocellulosic Biomass. Biore- 
source Technology, 100, 10-18. http://dx.doi.org/10.1016/j.biortech.2008.05.027

[38] Chandra, R.P., Bura, R., Mabee, W.E., Berlin, A., Pan, X. and Saddler, J.N. (2007) Substrate Pretreatment: The Key to Effective Enzymatic Hydrolysis of Lignocellulosics? Advances in Biochemical Engineering/Biotechnology, 108, 69-73. http://dx.doi.org/10.1007/10_2007_064

[39] Taherzadeh, M. and Karimi, K. (2008) Pretreatment of Lignocellulosic Wastes to Improve Ethanol and Biogas Production: A Review. International Journal of Molecular Sciences, 9, 1621-1651. http://dx.doi.org/10.3390/ijms9091621

[40] Glasser, W.G., Northey, R.A. and Schultz, T.P. (2000) Lignin: Historical, Biological, and Materials Perspectives. American Chemical Society, Washington DC.

[41] Belgacem, M.N. and Gandini, A. (2008) Monomers, Polymers and Composites from Renewable Resources. In: Cosmochim Acta, Elsevier, Amsterdam, 1803-1807.

[42] Francis, R.C., Bolton, T.S., Abdoulmoumine, N., Lavrykova, N. and Bose, S.K. (2008) Positive and Negative Aspects of Soda/Anthraquinone Pulping of Hardwoods. Bioresource Technology, 99, 8453-8457. http://dx.doi.org/10.1016/j.biortech.2008.02.055

[43] Muguet, M.C.S., Pedrazzi, C. and Colodette, J.L. (2010) Xylan Deposition onto Eucalypt Pulp Fibers during Oxygen Delignification. Holzforschung, 65, 605-612.

[44] Santa Anna LMM (2008) III Seminar on Pulp and Paper: Biorefinery \& Biopulping and Their Impact on the Pulp Industry. Viçosa.

[45] Galbe, M. and Zacchi, G. (2007) Pretreatment of Lignocellulosic Materials for Efficient Bioethanol Production. Advances in Biochemical Engineering/Biotechnology, 108, 41-65. http://dx.doi.org/10.1007/10_2007_070

[46] Yoshida, M., Liu, Y., Uchida, S., Kawarada, K., Ukagami, Y., Ichinose, H., Kaneko, S. and Fukuda, K. (2008) Effects of Cellulose Crystallinity, Hemicellulose, and Lignin on the Enzymatic Hydrolysis of Miscanthus sinensis to Monosaccharides. Bioscience, Biotechnology, and Biochemistry, 72, 805-810. http://dx.doi.org/10.1271/bbb.70689

[47] Santos, F.A., Queiroz, J.H., Colodette, J.L., Manfredi, M., Queiroz, M.E.L.R., Caldas, C.S. and Soares, F.E.F. (2014) Otimização do pré-tratamento hidrotérmico da palha de cana-de-açúcar visando à produção de etanol celulósico. Química Nova, 37, 56-62. http://dx.doi.org/10.1590/S0100-40422014000100011

[48] Kautto, J., Realff, M.J. and Ragauskas, A.J. (2013) Design and Simulation of an Organosolv Process for Bioethanol Production. Biomass Conversion and Biorefinery, 3, 199-212. http://dx.doi.org/10.1007/s13399-013-0074-6

[49] Teramoto, Y., Tanaka, N., Lee, S.H. and Endo, T. (2008) Pretreatment of Eucalyptus Wood Chips for Enzymatic Saccharification Using Combined Sulfuric Acid-Free Ethanol Cooking and Ball Milling. Biotechnology and Bioengineering, 99, 75-85. http://dx.doi.org/10.1002/bit.21522

[50] Hsu, T. (1996) Pretreatment of Biomass. In: Wyman, C., Ed., Handbook on Bioethanol: Production and Utilization, Taylor \& Francis, Washington DC, 179-212.

[51] Balat, M., Balat, H. and Oz, C. (2008) Progress in Bioethanol Processing. Progress in Energy and Combustion Science, 34, 551-573. http://dx.doi.org/10.1016/j.pecs.2007.11.001

[52] Iyer, P.V., Wu, Z.W., Kim, S.B. and Lee, Y.Y. (1996) Ammonia Recycled Percolation Process for Pretreatment of Herbaceous Biomass. Applied Biochemistry and Biotechnology, 57-58, 121-132. http://dx.doi.org/10.1007/BF02941693

[53] Kim, T.H., Kim, J.S., Sunwoo, C. and Lee, Y.Y. (2003) Pretreatment of Corn Stover by Aqueous Ammonia. Bioresource Technology, 90, 39-47. http://dx.doi.org/10.1016/S0960-8524(03)00097-X

[54] Santos, F., Queiroz, J.H., Colodette, J. and Souza, C.J. (2013) Produção de etanol celulósico a partir da cana-de-açúcar. In: Santos, F., Colodette, J. and Queiroz, J.H., Eds., Bioenergia e Biorrefinaria-Cana-de-Açúcar e Espécies Florestais, Federal University of Viçosa, Viçosa, 129-164.

[55] Quesada, J., Rubio, M. and Gómez, D. (1999) Ozonation of Lignin Rich Solid Fractions from Corn Stalks. Journal of Wood Chemistry and Technology, 19, 115-137. http://dx.doi.org/10.1080/02773819909349603

[56] Sun, Y. and Cheng, J.Y. (2002) Hydrolysis of Lignocellulosic Materials for Ethanol Production: A Review. Bioresource Technology, 83, 1-11. http://dx.doi.org/10.1016/S0960-8524(01)00212-7

[57] Zhao, X.B., Cheng, K.K. and Liu, D.H. (2009) Organosolv Pretreatment of Lignocellulosic Biomass for Enzymatic Hydrolysis. Applied Microbiology and Biotechnology, 82, 815-827. http://dx.doi.org/10.1007/s00253-009-1883-1

[58] Isroi, Millati, R., Syamsiah, S., Niklasson, C., Cahyanto, M.N., Lundquist, K. and Taherzadeh, M.J. (2011) Biological Pretreatment of Lignocelluloses with White-Rot Fungi and Its Applications: A Review. BioResources, 6, 5224-5259.

[59] Cardoso, M., Oliveira, E.D. and Passos, M.L. (2009) Chemical Composition and Physical Properties of Black Liquors and Their Effects on Liquor Recovery Operation in Brazilian Pulp Mills. Fuel, 88, 756-763. http://dx.doi.org/10.1016/j.fuel.2008.10.016 
[60] de Almeida, D.P. and Gomide, J.L. (2013) Anthraquinone and Surfactant Effect on Soda Pulping. O Papel, 74, 53-56.

[61] Gomide, J.L. and Oliveira, R.C. (1980) Eficiência da antraquinona na polpação alcalina do eucalipto. O Papel, 41, 67-72.

[62] Silva Jr., F.G. and Barrichelo, L.E.G. (1995) Conversion of the Kraft Process in Soda-DDA (Disodium Salt of 1,4-dihydro-9,10-dihydroxy Anthracene) for Eucalypt. Proceedings of the 1995 Pulping Conference, Chicago, 2, 757.

[63] Sarkanen, K.V., Hrutfiord, B.F., Johanson, L.N. and Gardner, H.S. (1970) Kraft Odor. Tappi Journal, 53, $766-783$.

[64] D’Almeida, M.L.O. (1985) Formação de compostos malcheirosos durante o processo de polpação sulfato. O Papel, 46, 65-68.

[65] Chai, X.S., Liu, P.H. and Zhu, J.Y. (2000) Analysis of Volatile Organic Sulphur Compounds in Kraft Liquors by Full Evaporation Headspace Gas Chromatography. Journal of Pulp and Paper Science, 26, 167-172.

[66] Silva, F.J., Gomide, J.L. and Colodette, J.L. (2002) Effects of Sulfidity Reduction and Anthraquinone Addition on Pollutant Emission and Quality of Eucalyptus Kraft Pulp. Tappi Journal, 1, 1-9.

[67] Macleod, J.M., Fleming, B.I., Kubes, G.J. and Bolker, H.I. (1980) Strengths of Kraft-AQ (Anthraquinone) and Soda-AQ Pulps. (1). Bleachable-Grade Pulps. Tappi, 63, 57.

[68] Dimmel, D.R. (2000) Method for the Delignification of Lignocellulosic Material by Adding a Dialkyl Substituted Octahydroanthraquinone. US Patent 6,156,155.

[69] Muurinen, E. (2000) Organosolv Pulping, A Review and Distillation Study Related to Peroxyacid Pulping. Dissertation, University of Oulu, Oulu, 314 p.

[70] Lora, J.H. and Aziz, S. (1985) Organosolv Pulping: A Versatile Approach to Wood Refining. Tappi Journal, 68, 94-97.

[71] Young, R.A. and Baierl, K.W. (1985) Ester Pulping of Wood: A Revolutionary Process. Southern Pulp Paper, 48, 1517.

[72] Dahlmann, G. and Schroeter, M.C. (1990) Pulping of Spruce and Pine with Alcohol and Alkali by the Organocell Process. 1990 Tappi Pulping Conference, Toronto, 14-17 October 1990, 657-661.

[73] Funaoka, M. and Abe, I. (1989) Rapid Separation of Wood into Carbohydrate and Lignin with Concentrated AcidPhenol System. Tappi Journal, 72, 145-149.

[74] Gottlieb, K., Preuss, A.W., Meckel, J. and Berg, A. (1992) Acetocell Pulping of Spruce and Chlorine-Free Bleaching. 1992 Solvent Pulping Symposium Notes, Boston, 35-39.

[75] Hamelinck, C.N., Van Hooijdonk, G. and Faaij, A.P.C. (2005) Ethanol from Lignocellulosic Biomass: Techno-Economic Performance in Short-, Middle- and Long Term. Biomass and Bioenergy, 28, 384-410. http://dx.doi.org/10.1016/j.biombioe.2004.09.002

[76] Rousu, P., Rousu, P. and Anttila, J. (2002) Sustainable Pulp Production from Agricultural Waste. Resources, Conservation and Recycling, 35, 85-103. http://dx.doi.org/10.1016/S0921-3449(01)00124-0

[77] Liitiä, T., Mikkonen, H., Uusitalo, J., Tamminen, T. and Colodette, J.L. (2011) Organosolv Pretreatment of Lignocellulosics for Bioethanol Production. 5th International Colloquium on Eucalyptus Pulp, Porto Seguro-BA, 9-12 May 2011, 12 p.

[78] Pérez, J., Muñoz-Dorado, J., de la Rubia, T. and Martínez, J. (2002) Biodegradation and Biological Treatments of Cellulose, Hemicellulose and Lignin: An Overview. International Microbiology, 5, 53-63. http://dx.doi.org/10.1007/s10123-002-0062-3

[79] Sweeney, M.D. and Xu, F. (2012) Biomass Converting Enzymes as Industrial Biocatalysts for Fuels and Chemicals: Recent Developments. Catalysts, 2, 244-263. http://dx.doi.org/10.3390/catal2020244

[80] Ratanakhanokchai, K., Waeonukul, R., Pason, P., Aachaapaikoon, C., Kyu, K.L., Sakka, K., Kosugi, A. and Mori, Y. (2013) Paenibacillus curdlanolyticus Strain B-6 Multienzyme Complex: A Novel System for Biomass Utilization. In: Biomass Now-Cultivation and Utilization, InTech, Rijeka, 460 p. http://dx.doi.org/10.5772/51820

[81] Koshijima, T. and Watanabe, T. (2003) Association between Lignin and Carbohydrates in Wood and Other Plant Tissues. Springer, Berlin. http://dx.doi.org/10.1007/978-3-662-05191-7

[82] Achyuthan, K.E., Achyuthan, A.M., Adams, P.D., Dirk, S.M., Harper, J.C., Simmons, B.A. and Singh, A.K. (2010) Supramolecular Self-Assembled Chaos: Polyphenolic Lignin’s Barrier to Cost-Effective Lignocellulosic Biofuels. Molecules, 15, 8641-8688. http://dx.doi.org/10.3390/molecules15118641

[83] Iiyama, K., Lam, T.B.T. and Stone, B.A. (1994) Covalent Cross-Links in the Cell Wall. Plant Physiology, 104, 315320.

[84] Eggeling, L. (1983) Lignin-An Exceptional Biopolymer...and a Rich Resource? Trends in Biotechnology, 1, $123-127$. http://dx.doi.org/10.1016/0167-7799(83)90036-7

[85] Ruiz-Dueñas, F.J. and Martínez, A.T. (2009) Microbial Degradation of Lignin: How a Bulky Recalcitrant Polymer Is 
Efficiently Recycled in Nature and How We Can Take Advantage of This. Microbial Biotechnology, 2, 164-177. http://dx.doi.org/10.1111/j.1751-7915.2008.00078.x

[86] Kersten, P. and Cullen, D. (2007) Extracellular Oxidative Systems of the Lignin-Degrading Basidiomycete Phanerochaete chrysosporium. Fungal Genetics and Biology, 44, 77-87. http://dx.doi.org/10.1016/j.fgb.2006.07.007

[87] Martínez, A.T., Speranza, M., Ruiz-Dueñas, F.J., Ferreira, P., Camarero, S., Guillén, F., Martínez, M.J., Gutiérrez, A. and Del Rio, J.C. (2005) Biodegradation of Lignocellulosics: Microbial, Chemical and Enzymatic Aspects of Fungal Attack to Lignin. International Microbiology, 8, 195-204.

[88] Maciel, M.J.M., Silva, A.C. and Ribeiro, H.C.T. (2010) Industrial and Biotechnological Applications of Ligninolytic Enzymes of the Basidiomycota: A Review. Electronic Journal of Biotechnology, 13, 14-15.

[89] Kirk, T.K. and Farrell, R.L. (1987) Enzymatic “Combustion”: The Microbial Degradation of Lignin. Annual Review of Microbiology, 41, 465-501. http://dx.doi.org/10.1146/annurev.mi.41.100187.002341

[90] Pérez-Boada, M., Ruiz-Dueñas, F.J., Pogni, R., Basosi, R., Choinowski, T., Martínez, M.J., Piontek, K. and Martínez, A.T. (2005) Versatile Peroxidase Oxidation of High Redox Potential Aromatic Compounds: Site-Directed Mutagenesis, Spectroscopic and Crystallographic Investigations of Three Long-Range Electron Transfer Pathways. Journal of Molecular Biology, 354, 385-402. http://dx.doi.org/10.1016/j.jmb.2005.09.047

[91] Ibarra, D., Camarero, S., Romero, J., Martínez, M.J. and Martínez, A.T. (2006) Integrating Laccase-Mediator Treatment into an Industrial-Type Sequence for Totally Chlorine Free Bleaching Eucalypt Kraft Pulp. Journal of Chemical Technology and Biotechnology, 81, 1159-1165. http://dx.doi.org/10.1002/jctb.1485

[92] Ghatora, S.K., Chadha, B.S., Saini, H.S., Bhat, M.K. and Faulds, C.B. (2006) Diversity of Plant Cell Wall Esterases in Thermophilic and Thermotolerant Fungi. Journal of Biotechnology, 125, 434-445. http://dx.doi.org/10.1016/j.jbiotec.2006.04.005

[93] Lynd, L.R., Weimer, P.J., Van Zyl, W.H. and Pretorius, I.S. (2002) Microbial Cellulose Utilization: Fundamentals and Biotechnology. Microbiology and Molecular Biology Reviews, 66, 506-577. http://dx.doi.org/10.1128/MMBR.66.3.506-577.2002

[94] Bayer, E.A., Belaich, J.P., Shoham, Y. and Lamed, R. (2004) The Cellulosomes: Multienzyme Machines for Degradation of Plant Cell Wall Polysaccharides. Annual Review of Microbiology, 58, 521-554. http://dx.doi.org/10.1146/annurev.micro.57.030502.091022

[95] Saloheimo, M., Paloheimo, M., Hakola, S., Pere, J., Swanson, B., Nyyssonen, E., Bhatia, A., Ward, M. and Penttila, M. (2002) Swollenin, a Trichoderma reesei Protein with Sequence Similarity to the Plant Expansins, Exhibits Disruption Activity on Cellulosic Materials. European Journal of Biochemistry, 269, 4202-4211. http://dx.doi.org/10.1046/j.1432-1033.2002.03095.x

[96] Baldrian, P. and Valaskova, V. (2008) Degradation of Cellulose by Basidiomycetous Fungi. FEMS Microbiology Reviews, 32, 501-521. http://dx.doi.org/10.1111/j.1574-6976.2008.00106.x

[97] Gutiérrez, A., Del Río, J.C., Martínez, M.J. and Martínez, A.T. (2001) The Biotechnological Control of Pitch in Paper Pulp Manufacturing. Trends in Biotechnology, 19, 340-348. http://dx.doi.org/10.1016/S0167-7799(01)01705-X

[98] Calero-Rueda, O., Plou, F.J., Ballesteros, A., Martínez, A.T. and Martínez, M.J. (2002) Production, Isolation and Characterization of a Sterol Esterase from Ophiostoma piceae. Biochimica et Biophysica Acta (BBA)-Proteins and Proteomics, 1599, 28-35. http://dx.doi.org/10.1016/S1570-9639(02)00378-3

[99] Mccann, M.C. and Carpita, N.C. (2008) Designing the Deconstruction of Plant Cell Walls. Current Opinion in Plant Biology, 11, 314-320. http://dx.doi.org/10.1016/j.pbi.2008.04.001

[100] Gilbert, H.J. (2010) The Biochemistry and Strucutural Biology of Plant Cell Wall Deconstruction. Plant Physiology, 153, 444-455. http://dx.doi.org/10.1104/pp.110.156646 
Scientific Research Publishing (SCIRP) is one of the largest Open Access journal publishers. It is currently publishing more than 200 open access, online, peer-reviewed journals covering a wide range of academic disciplines. SCIRP serves the worldwide academic communities and contributes to the progress and application of science with its publication.

Other selected journals from SCIRP are listed as below. Submit your manuscript to us via either submit@scirp.org or Online Submission Portal.
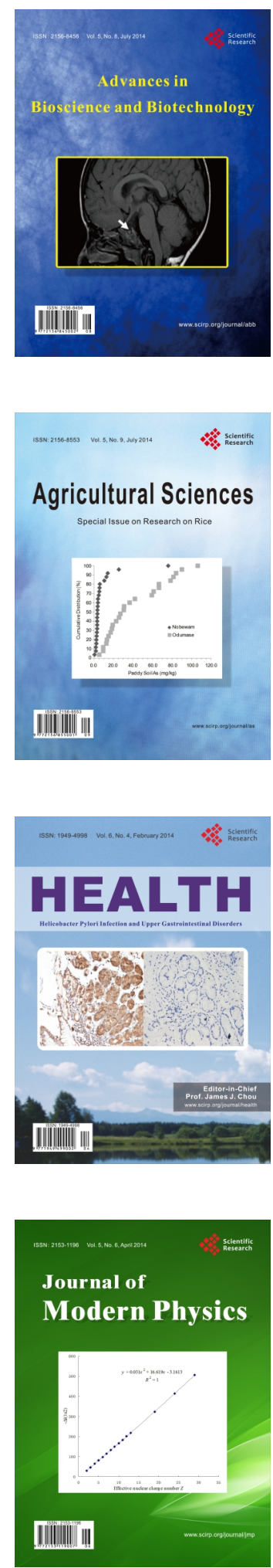
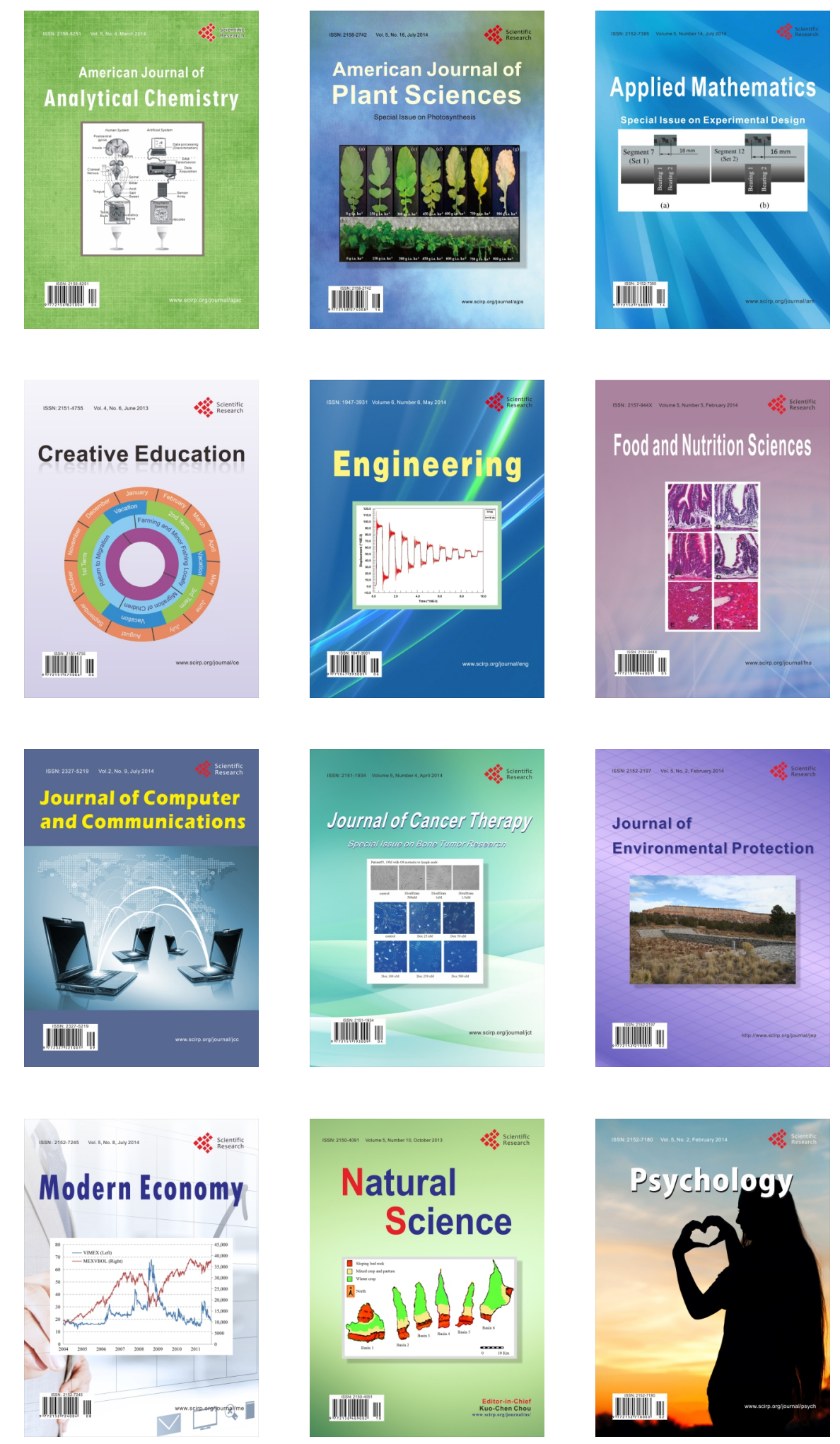